Check for updates

London, UK

Cite this as: BMJ 2021;374:n1702 http://dx.doi.org/10.1136/bmj.n1702 Published: 05 July 2021

\section{Sixty seconds on ... EU covid certificates}

Ingrid Torjesen

\section{Europe-wide, covid secure travel is finally here...}

Unfortunately, many people in the UK aren't eligible so can't take advantage of this.

\section{Because of Brexit?}

Indirectly. As the UK has left the EU, it now has separate systems and regulations and its citizens lost the right to free movement. Meanwhile, the EU has launched a digital covid certificate to facilitate free movement, which will be issued and recognised by all EU states.

\section{How does it work?}

The certificate contains a $Q R$ code showing that the bearer has been fully vaccinated and tested negative for, or recently recovered from, covid-19. ${ }^{1}$ Fully vaccinated EU citizens will be exempt from travel related testing and quarantine across the region 14 days after having received their last dose. ${ }^{1}$ Only UK residents who are citizens of EU member states living here may be eligible for one.

\section{Sounds like the NHS covid pass}

This is a different system so is not automatically recognised by the EU, although some individual EU countries, including Spain and Greece, are accepting the NHS covid pass. ${ }^{2}$ The technologies behind the two systems are similar, so the EU and the UK are working on a mutual recognition agreement before the peak summer holiday season kicks in.

\section{Great, so can we book a cheap August break in the Med?}

Not so fast. Check which vaccine you had first. If it's AstraZeneca then you should be covered, but you'll need to check the batch numbers to be sure.

\section{I think it was $4120 \mathrm{Z001}$...}

Sorry, looks like you will be holidaying in Cornwall this year, if you can find any accommodation you can afford. ${ }^{3}$ Unfortunately batch numbers 4120Z001, 4120Z002, and 4120Z003 are Covishield which is not recognised by the EU.

\section{But isn't all AstraZeneca recognised?}

Unfortunately not. While the two vaccines are identical, Covishield was made at the Serum Institute in India rather than in the UK or EU. EU member states only recognise vaccines that received EU marketing authorisation. The European Medicines Agency hasn't approved Covishield because the EU isn't receiving any Covishield doses.

\section{Bureaucratic nonsense!}

Maybe, but there is still hope. Individual EU member states can decide to recognise other vaccines, ${ }^{1}$ and the World Health Organization has approved Covishield for emergency use. Some countries already accept other vaccines-for example, Greece accepts China’s Sinovac, Russia’s Sputnik V, and several others.

European Commission. EU digital covid certificate. https://ec.europa.eu/info/live-work-travel-eu/coronavirus-response/safe-covid-19-vaccines-europeans/eudigital-covid-certificate_en.

2 The EU vaccine "passport" and what it means for travel. BBC News. 3 July 2021. www.bbc.co.uk/news/explainers-57665765.

3 Catling L. Father of three Tory councillor slams staycation firms for “exploiting”families after he is quoted $£ 71000$ for a week's holiday in Cornwall. Daily Mail. 4 July 2021. www.dailymail.co.uk/news/article-9754801/Father-three-quoted-71k-weeks-stay-Cornwall-holiday-home.html. 